\title{
WYCHOWANIE PAŃSTWOWE W DRUGIEJ RZECZYPOSPOLITEJ W ŚWIETLE PROGRAMÓW SZKOLNYCH (PO WPROWADZENIU REFORMY OŚWIATOWEJ Z 1932 ROKU)
}

\begin{abstract}
„Ingerencja państw w zakresie wychowania i oświaty powszechnej będzie w przyszłości coraz silniejsza i że tym samym ustawodawstwo oświatowe będzie musiało z biegiem czasu objąć wszystkie najbardziej subtelne zagadnienia $w$ tej dziedzinie ido nich przystosować swoją treść normatywną"
\end{abstract}

(fragment z podręcznika dla nauczycieli z 1928 r.) ${ }^{1}$.

Streszczenie: Lansowana przez obóz Józefa Piłsudskiego idea budowy wielkomocarstwowej Polski wiązała się z potrzebą stworzenia silnej organizacji państwowej oraz ukształtowania skonsolidowanego, homogenicznego światopoglądowo społeczeństwa, solidarnie i wytrwale pracującego na rzecz dobra najwyższego, czyli - w retoryce sanacyjnej - państwa. Nie mogło się to odbyć bez przyjęcia przez obóz władzy odpowiedniej doktryny wychowawczej i przekucia jej w sprawnie działający system edukacyjny obejmujący jak najszersze kręgi społeczne. W efekcie krystalizująca się po 1926 r. ideologia wychowawcza sanacji zyskała miano tzw. wychowania państwowego ${ }^{2}$, przez które, urabiając pożądany ideał obywatela-państwowca, spodziewano się „uzdrowić” stosunki społeczne w kraju. Jego konceptualizacją stała się reforma szkolnictwa z 1932 r. przynosząca nową ramę programową. Wytykając starym programom miałkość celów i zbytnią ogólnikowość, autorzy nowej podstawy stawiali na wybitnie praktyczny charakter

\footnotetext{
${ }^{1}$ Śliwiński, 1928, Ustawodawstwo szkolne i organizacja polskich władz szkolnych oraz szkolnictwa wszystkich stopni w wszystkich stopni w Polsce Odrodzonej, s. 8.

${ }^{2}$ Niekiedy określanego również jako obywatelsko-państwowe. Por. Kijas 1932; Drzewiecki 1934b, s. 21-44; Pohoska 1934; Malinowski 2015, s. 26-38, 64-74.
} 
nauczania. Hasło, jakie miało mu przyświecać, to Polska i jej kultura. Spodziewano się bowiem, iż położenie akcentu na dorobek kulturalny Polski wniesie walor integrujący w zróżnicowane etnicznie społeczeństwo II Rzeczypospolitej. Dawano w ten sposób do zrozumienia, że Polska to spuścizna wielu nacji, które tworzyły jej mozaikę kulturową w swoisty sposób przyczyniającą się do ciągłości państwa, pomimo jego formalnie ponad stuletniej nieobecności zarówno na mapach, jaki i w ludzkiej świadomości. W myśl nowych założeń, najważniejszym dla każdego obywatela winno stać się poszanowanie tej wartości, jakim było państwo, oddanie dla jego rozwoju, kształtowanie poczucia odpowiedzialności obywatelskiej niezależnie od przynależności do grupy narodowej. Krzewienie tychże wzorców musiało odbywać się na wielu płaszczyznach życia społecznego, nie tylko instytucjonalnej. Stąd kładziono nacisk na powiązanie pracy dydaktycznej z oddziaływaniem wychowawczym, pracy szkolnej z pozaszkolną. Niniejszy artykuł zajmuje się analizą założeń programów szkolnych, szkoły powszechnej i średniej pod kątem treści związanych $\mathrm{z}$ wychowaniem państwowym.

Słowa kluczowe: wychowanie państwowe, ideologia, programy szkolne, sanacja, integracja

\section{WPROWADZENIE}

W okresie międzywojennym jednym z najważniejszych zadań odradzającego się państwa polskiego było stworzenie ujednoliconego systemu edukacyjnego i zaprowadzenie efektywnej polityki oświatowej. Władze państwowe słusznie dostrzegały w niej kluczowy instrument do unifikacji zróżnicowanych pod wieloma względami regionów II Rzeczypospolitej. Zapóźnienia w dziedzinie oświaty, podyktowane ponadwiekowym okresem zaborów, wymagały podjęcia szeregu działań zapoczątkowanych już w 1919 r. wprowadzeniem obowiązku szkolnego. Jakkolwiek przyjęte $\mathrm{w}$ tym względzie rozwiązania przez cały okres międzywojenny były podyktowane aktualnie dominującą ideologią polityczną. Na przestrzeni dwóch dziesięcioleci kształt wychowania w jego teoretycznym i praktycznym wymiarze zależał najpierw od ideologii rządzącego obozu narodowej demokracji, forsującego tzw. ideał wychowania narodowego, a następnie, związanego z postacią Józefa Piłsudskiego, obozu sanacyjnego, realizującego tzw. wychowanie państwowe. To ostatnie po przewrocie majowym w 1926 r. wywierało największy wpływ na kształtowanie się idei pedagogicznych w II Rzeczypospolitej. Ostatecznym celem środowiska sanacyjnego było stworzenie państwa o ponadklasowym i ponadnarodowym charakterze, gdzie wszyscy obywatele mieli pracować dla dobra wspólnego, a interes państwa winien być jednocześnie indywidualnym priorytetem w działalności każdej jednostki, co jednak jawiło się procesem niezwykle trudnym i skomplikowanym, biorąc pod uwagę ówczesne realia społeczno-gospodarcze i stosunki narodowościowe. Stąd też polityka oświatowa nie od razu przyjęła konsekwentny charakter. Najbardziej twórczy i efektywny czas w tej materii 
przypada na lata 1928-1933, kiedy to sformułowano podstawy edukacyjne ideologii wychowywania państwowego i podjęto się ich wdrożenia poprzez przeprowadzenie reformy szkolnej i uniwersyteckiej.

\section{„WOŁANIE O WIELKĄ IDEE” \\ PRACE NAD NOWYMI PROGRAMAMI NAUCZANIA W MYŚL ZAŁOŻEŃ IDEOWYCH REFORMY OŚWIATOWEJ}

Ustawa oświatowa z 1932 r., której pomysłodawcą był ówczesny szef Ministerstwa Wyznań Religijnych i Oświecenia Publicznego (MWRiOP) Janusz Jędrzejewicz, obok haseł reformy polskiego szkolnictwa głosiła postulat ogólnospołecznej sanacji i wzmocnienia roli państwa poprzez praktykę edukacyjną. „Przez szkołę należy zmieniać nasz stosunek do państwa" - myśl ta stała się przewodnią w założeniach programowo-organizacyjnych nauczania i wychowania reformowanej szkoły. Konstrukcja i treści nauczania zawarte w nowo wypracowanych programach szkolnych wszystkich szczebli edukacyjnych najlepiej oddają wagę zagadnień z zakresu wychowania państwowego.

Konieczność reformy programowej w oparciu o „[...] adaptację myślenia polskiego społeczeństwa do faktu niepodległości” (Radziwiłł 1966, s. 41) była dostrzegana już w połowie lat 20. XX wieku. Większość publikacji autorów sanacyjnych z tego

${ }^{3}$ Periodyzacja prowadzonej przez obóz sanacji polityki oświatowej jest traktowana w historiografii przedmiotu różnie. Najczęściej badacze przychylają się do podziału zaproponowanego przez Feliksa Wojciecha Araszkiewicza (Magiera 2003, s. 15; Malinowski 2015, passim) bądź Annę Radziwiłł (K. Bartnicka 1972, s. 70). Według tej autorki pierwszy okres przypada na lata 1926-1928 i charakteryzuje się niewielkim zainteresowaniem sprawami wychowawczymi, a wszelkie działania koncentrują się na problemie stabilizacji władzy; drugi (1928-1933) to czas ofensywy wychowawczej sanacji i sformułowania ideologii wychowawczej oraz przeprowadzenia reformy szkolnictwa; kolejny okres zawiera się w latach: 1934-1937 skupiając się na realizacji reformy i założeń teoretycznych, ale też przynosząc widoczne zahamowanie pracy teoretycznej i nieznaczne wycofanie się z wychowania państwowego; ostanie dwa lata (1937-1939) to powtórna aktywizacja sanacji w sprawach wychowawczych pod hasłami wychowania wojskowego (Radziwiłł 1966, s. 44; Jakubiak 2003, s. 253-266). Inaczej na tę sprawę zapatruje się F. Araszkiewicz, który wyróżnia trzy okresy w rozwoju ideologii wychowania sanacyjnego. Pierwszy to lata 1926-1932 kiedy wypracowano teoretyczne i ustawowe podstawy edukacji obywatelsko-państwowej. Następny, obejmujący okres od 1932 do 1935 r., to czas realizacji ustawy Jędrzejewiczowskiej i pogłębiania założeń teoretycznych. Ostatni trwał do wybuchu wojny i przyniósł zwrot w kierunku wychowania obywatelsko-narodowego, łączącego trzy najważniejsze idee; naród, państwo, Bóg. F. W. Araszkiewicz 1978, s. 21.

${ }^{4}$ Prace nad przygotowaniem nowych programów były podejmowane w drugiej połowie lat dwudziestych wielokrotnie; już na Zjeździe Delegatów Zrzeszenia Polskiego Nauczycielstwa Szkół Początkowych (ZPNSP) w Warszawie w dniu 31 października 1926 r. Romuald Petrykowski określił, iż „[...] program ten winien tkwić w psychice dziecka, a wierzchołkami sięgać przyszłego 
okresu propagowała postulaty: „zapotrzebowania na ideologię”, „wołania o wielką ideę" czy konieczność stworzenia „własnego ideału wychowawczego” (Jędrzejewicz 1930; Czerwiński 1934; Skwarczyński 1934). W objaśnieniach do projektu ustawy o ustroju szkolnictwa z sierpnia 1927 r., podkreślano jak „,[... jaskrawa potrzeba jest takiej ustawy [...], z której wynika, że państwo nasze odziedziczyło po zaborcach fragmenty ustawodawstwa szkolnego obcego nam duchem, nie odpowiadającego współczesnym potrzebom, że jako młody organizm państwowy pozbawieni jesteśmy własnej państwowej tradycji z najbliższej przeszłości, jak w innych krajach kulturalnych, stąd musimy budować całość systemu szkolnego" (Ustawa o ustroju szkolnictwa... 1927, s. 3; Araszkiewicz 1971, s. 555). Na Kongresie Pedagogicznym w Poznaniu w lipcu 1929 r. Sławomir Czerwiński, ówczesny Minister WRiOP, dokonał oficjalnej proklamacji wychowania obywatelsko-państwowego jako nowej ideologii wychowawczej sanacji (Radziwiłł 2014, s. 262). W swym wystąpieniu zdecydowanie podkreślał, że wychowanie i nauczanie w niepodległym państwie polskim musi się znacząco różnić od tego z czasów niewoli. Oceniając dotychczasowe programy kształcenia, S. Czerwiński najczęściej krytykował je za ich ogólnikowość, całkowity brak idei przewodniej i „pierwiastków” obywatelskopaństwowych ${ }^{5}$. Dlatego w swych rozważaniach na temat założeń programowych starał się nakreślić ramy nowego modelu wychowawczego, kształtującego przyszłą postać patriotyzmu. Wzorzec ten, łączący w postawie obywatelskiej dwie natury bojownika i pracownika, miały wyróżniać: „»dzielność życiowa«, silna wola, potężna energia, wiara we własne siły, zdolność do czynu i pracy, dynamizm, wytrwałość, honor, zdyscyplinowanie w stosunku do zbiorowości, a przede wszystkim lojalność i ofiarność w stosunku do państwa” (Radziwiłł 1966, s. 48). Cytowana wcześniej

obywatela w społeczeństwie" (Petrykowski 1927, s. 6). Zagadnienia wychowania państwowego wprowadzono również pod obrady kongresów pedagogicznych w latach 1929 i 1931. Omawiano wówczas nowe zadania szkoły, najwięcej dyskutowano o programach szkolnych. Rozwiązania te niewątpliwie sprzyjały dopracowaniu i umocnieniu ideologii wychowawczej. Nieodzowne stało się również włączenie środowiska nauczycielskiego do prac nad wdrażaniem nowej doktryny. W samym 1930 r. przeszkolono w zakresie problematyki wychowania państwowego około 8 tys. nauczycieli szkół powszechnych i średnich oraz pracowników administracji oświatowej (Araszkiewicz 1978; Iwanicki 1986, s. 34).

${ }^{5}$ Sławomir Czerwiński wskazywał na konieczność konstruowania programów nauczania w duchu obywatelskim (Czerwiński 1934, s. 91). Spośród innych teoretyków zajmujących się analizą programową podobne stanowisko zajęli J.S. Bystroń (Bystroń 1934) i J. Michałowska. Ta ostania zarzucała dominującej funkcji nauczaniaw szkołach pozbawienie jakiegokolwiek wymiaru wychowawczego (Michałowska 1935, s. 8). Z kolei zdaniem W. Grabowskiej krytyka powojennych programów nauczania dokonana przez obóz sanacyjny była słuszna, aczkolwiek jednostronna. Podkreśla, że przedstawiały one również szereg wartości, np. przygotowywały do życia i wypełniania obowiązków społecznych, podnosiły świadomość narodową czy rozwijały poczucie odpowiedzialności za państwo. Szerzej: Garbowska 1976, s. 78; Magiera 2003, s. 54. 
Anna Radziwiłł przedstawiony koncept określiła jako sanacyjny program „przebudowy psychiki narodu”, zmiany „duszy narodu”, wychowania „nowego człowieka” czy „przebudowy patriotyzmu”. Polityka oświatowa miała utrwalić w świadomości zbiorowej fakt istnienia niepodległej Polski i to Polski rządzonej przez sanację (Radziwiłł 1966, s. 50-51). Prace nad programami nauczania w latach 1930-1935 przebiegały $\mathrm{w}$ dwóch etapach i skutkowały stworzeniem projektów dla poszczególnych szczebli edukacyjnych ${ }^{6}$. Podjęte działania wiązały się jednak z licznymi trudnościami wynikającymi chociażby z konieczności ujęcia i powiązania założeń ideowych zapowiedzianych w ustawie. Poza ukierunkowaniem „obywatelskopaństwowym" w dziedzinie programowej ustawa zawierała wskazówki zalecające skojarzenie nauczania i wychowania z najbliższym środowiskiem ucznia, szczególnie w szkole powszechnej (art. 11\$2), czy uwzględnienie „praktycznych potrzeb życia” w programach gimnazjum (art. 21\$2). Natomiast, „potrzeby życia gospodarczego" winny być eksponowane w czasie całej nauki szkolnej (Ustawa o ustroju szkolnym Dz.U. $1932 \mathrm{nr} 38$ poz. 389). Sama ustawa jako stosunkowo ogólna wymagała przełożenia na język programów i podręczników. Trzeba było, jak określa to A. Radziwiłł, zacząć jakby „wewnętrzną” reformę szkolnictwa (Radziwiłł 2014, s. 280; Kamińska 2014, s. 207-208). Niełatwym okazało się zwłaszcza dostosowanie treści społecznych, politycznych czy gospodarczych do poszczególnych etapów edukacyjnych przy jednoczesnym uwzględnieniu psychologicznych potrzeb i możliwości rozwojowych uczniów (Sadowska 2001, s. 235-237; Magiera 2003, s. 55-58). Nowatorstwem na tym polu wykazał się Jan Kuchta, który w sposób interdyscyplinarny okres pobierania nauki szkolnej podzielił na fazy: średniego dzieciństwa, późnego dzieciństwa, przedpokwitania, pokwitania i adolescencji (Kuchta 1934, s. 5). Ujęcie kwestii osobowości dziecka i założeń psychologii rozwojowej dziecka w konstruowaniu nowych programów było naówczas nowością

\footnotetext{
${ }^{6}$ Pierwszy trwający od 1930 r. opracował Wytyczne dla autorów programów szkół ogólnokształcacych. Szkoła powszechna. Gimnazjum. Wydane drukiem pod koniec czerwca 1932 r. precyzowały podstawy reformy i treści programowe wraz z ideałem wychowawczym. Drugi etap rozpoczynający się w październiku 1932 r. wiązał się z przeprowadzeniem kompleksowej analizy wychowawczej, psychologicznej i obywatelskiej pierwszej redakcji nowotworzonych programów. W maju $1933 \mathrm{r}$. wydano rękopis projektu programu dla publicznych szkół powszechnych i gimnazjum, który rozesłano do szkół i przedstawicieli związanych z oświatą i nauką w celu konsultacji i krytycznej oceny. W sierpniu następnego roku ukazał się drukiem program dla publicznych szkół powszechnych trzeciego stopnia z polskim językiem nauczania, a w drugiej połowie $1935 \mathrm{r}$. wydano takowy dla szkół pierwszego i drugiego stopnia. Por.: Wytyczne dla autorów programów szkół ogólnokształcących. Szkoła powszechna. Gimnazjum...1932; Wytyczne dla autorów programów szkół ogólnokształcących. Szkoła powszechna I i II stopnia o 5 i 6 nauczycielach...1934; Balicki 1934, s. 454-455. Prace nad przygotowaniem nowych programów szczegółowo przeanalizowali: Michałowska 1933, s. 9-49; Michałowska 1935, s. 8-16; Garbowska 1976, s. 78-93; Magiera 2003, s. 53-60.
} 
na skalę europejską ${ }^{7}$. Dotychczas do zagadnień tych nie przywiązywano większej wagi. Ponadto całość zagadnień programowych zamierzano wzbogacić również o zajęcia praktyczne. Podobne założenie miało spowodować wywarcie głębszego wpływu na realizację praktycznej i wychowawczej funkcji szkoły, polegającej na socjalizacji, skoncentrowanej na przygotowaniu do życia społecznego i państwowego najmłodszych obywateli (Sadowska 2001, s. 218-219; Magiera 2003, s. 60; Sadowska 2004, s. 83-93).

\section{ZAŁOŻENIA WYCHOWAWCZE NOWYCH PROGRAMÓW WRAZ Z GŁÓWNĄ OSIĄ PROGRAMOWĄ: „POLSKA I JEJ KULTURA”}

Uniwersalną wytyczną spajającą szczegółowe zalecenia odnośnie metodycznej i merytorycznej zawartości nowych programów nauczania, wspólną dla wszystkich szkół, stało sięzagadnienie wychowania państwowego. Sformułowanie dotyczące podstaw ideowych i wychowawczych nowej szkoły widniało we wstępie każdego programu szkolnego i głosiło, że: „Celem szkoły jest wychowanie i kształcenie młodzieży na świadomych swych obowiązków i twórczych obywateli Rzeczypospolitej. Zmierzając do osiągnięcia tego celu naczelnego - społeczno-obywatelskiego przygotowania swych wychowanków, szkoła musi wszechstronnie rozwijać ich osobowość przez urabianie w dziedzinie religijnej, moralnej, umysłowej i fizycznej [...], zdolniejszym zaś i dzielniejszym jednostkom ze wszelkich środowisk umożliwić osiągnięcie najwyższych szczebli naukowego i zawodowego wykształcenia" (Program nauki... z polskim językiem nauczania (tymczasowy)... 1934, s. VII; Sejm Rzeczypospolitej Polskiej. Okres III. Druk nr 508, s. 1.). Tak postawione zadanie szkoły oznaczało podporządkowanie wszystkich działań wychowawczych, nawet tych niezwiązanych bezpośrednio z ideologią, hasłu wychowania państwowego. Ono też było podstawowym czynnikiem decydującym o doborze i rozkładzie materiału nauczania, który miał służyć wychowaniu „użytecznego obywatela” (Felchner 2014, s. 16). Analizując ówczesne programy, można wskazać na trzy przyjęte zasady nauczania, są to: „[...] jak najszersze potraktowanie w programach wiedzy o państwie, »życiowość« czyli zbliżenie do potrzeb życia współczesnego oraz »nachylenie humanistyczne«, polegające m.in. na eksponowaniu twórczej roli jednostek. Cechy te stanowiły całość w ramach wspólnej platformy wychowawczej, której podstawą był stereotyp obywatela-państwowca. Właściwy stosunek do państwa, postawa

${ }^{7}$ Uwzględnienie założeń psychologicznych w polskich programach nauczania szczególnie podkreślał prof. Jean Piaget, dyrektor genewskiego Międzynarodowego Biura Wychowania, który gościł w naszym kraju w marcu 1933 r. Reformę programową uznał wówczas za „[...] umiejętne połączenie ideałów pedagogiki ze specyficznymi dążeniami polskimi” (Grochowski 1996, s. 80). 
obywatelska - wyrabiane poprzez działanie na stronę intelektualną, wolicjonalną i emocjonalną psychiki wychowanka, to więź wychowawcza w systemie nauczania tworzonym przez sanację" (Radziwiłł 1966, s. 104-106). Innymi słowy proces dydaktyczny wymagał spójności wychowawczej, która stawała się odtąd integralną częścią pracy dydaktycznej i odwrotnie. Zarówno nauczanie, jak i wychowanie w szkole miało na celu wytworzenie w uczniach jako przyszłych obywatelach głębokiego przeświadczenia, że ich działania służyć mają państwu, które jest dobrem ogółu. Szkoła winna zatem wypełniać założenia wychowania państwowego opartego na poszanowaniu pracy, narodowej kultury i tradycji. Podkreślał to już J. Jędrzejewicz, twierdząc, iż jednym $z$ ważniejszych celów wychowania jest „[...] przygotowanie młodzieży do pracy państwowo-obywatelskiej na każdym odcinku" (Juśko 2003, s. 10; Juśko www.kul.pl/files/803/biblioteczka_cyfrowa/ jusko_Patriotyzm_w_wychowaniu.pdf).

Realizacja wychowania państwowego w szkole została podporządkowana wytyczonej głównej „osi programowej” wyrażonej w naczelnym haśle podstawy programowej: „Polska i jej kultura”. W myśl tegoż sformułowania „[...] podstawą szkoły ogólnokształcącej winno stać się kształcenie ogólne młodego pokolenia, uwzględniające potrzeby życia społecznego, w szczególności życia gospodarczego" (Balicki 1934, s. 455). Programy szkolne zostały zintegrowane wokół dziedzictwa kultury polskiej, rozumianej jako państwo polskie, jego spuścizna duchowa i materialna. Przewodnią ideę programów tworzyła „rodzima” kultura, uwzględniająca również w odpowiednim zakresie dorobek kulturalny narodów rozwijających się w ramach Państwa Polskiego (Program nauki w publicznych szkołach... 1934, s. XXIII). Nauczanie w takiej konwencji nabierało zasadniczego znaczenia na lekcjach języka polskiego, historii, geografii, przyrody czy nauczania religijnego.

W odniesieniu do wychowania państwowego, MWRiOP, opracowując wytyczne dla autorów programów nauczania, powołało osobną „komisję wychowania obywatelskiego". Według przyjętych przez nią uchwał, podstawę wychowania obywatelskiego „(...)winno stanowić dążenie do rozwoju społecznego młodzieży, tj. wyrabianie w niej zmysłu społecznego, umiejętności i zdolności życia grupowego, harmonijnego współżycia, koleżeństwa, solidarności, karności społecznej, zdolności do współpracy i zbiorowych wysiłków, poczucia zbiorowej odpowiedzialności, a wreszcie budzenie kultu dla czynu społecznego i pracy ideowej" (Michałowska 1933 s. 37-38). Początkowo wychodzono z zamysłem opracowania odrębnego przedmiotu - „obywatelstwa” - który specjalnie znalazłby się zarówno w programie szkoły powszechnej, jak i średniej. W późniejszych pracach zespołu zaniechano jednak jego wprowadzenia. W zamian postanowiono rozłożyć treści ideologiczne możliwie na wszystkie przedmioty nauczania. „Naukę obywatelstwa” realizowano by w ramach lekcji historii, które w ostatnich klasach szkół powszech- 
nych i gimnazjalnych liczbowo przeważały. Postulaty komisji zostały ostatecznie zaaprobowane i zaimplementowane do nowych programów wraz z zatwierdzoną siatką godzinową (patrz tabela planów pracy szkoły powszechnej III stopnia i gimnazjum ogólnokształcącego).

Tabela1. Plan pracy szkoły powszechnej III stopnia

\begin{tabular}{|l|c|c|c|c|c|c|c|c|}
\hline \multirow{2}{*}{\multicolumn{1}{c|}{ Przedmioty }} & \multicolumn{9}{c|}{ Klasa } & \multirow{2}{*}{ Ogólem } \\
\cline { 2 - 10 } & I & II & III & IV & V & VI & VII & \\
\hline Religia & 2 & 2 & 2 & 2 & 2 & 2 & 2 & 14 \\
\hline Język polski & 7 & 7 & 7 & 7 & 5 & 5 & 5 & 43 \\
\hline Historia & - & - & - & - & 3 & 3 & $0 / 4^{*}$ & 8 \\
\hline Geografia & - & - & razem & razem & 3 & 3 & $4 / 0^{*}$ & 12,5 \\
\hline Przyroda & - & - & 4 & 5 & 3 & 3 & 4 & 14,5 \\
\hline Arytmetyka z geometrią & 3 & 4 & 4 & 4 & 4 & 4 & 4 & 27 \\
\hline Rysunek & 1 & 2 & 2 & 2 & 2 & 2 & 2 & 13 \\
\hline Zajęcia Praktyczne & 3 & 3 & 4 & 4 & 4 & 4 & 5 & 27 \\
\hline Śpiew & 1 & 2 & 2 & 2 & 2 & 2 & 2 & 13 \\
\hline Ćwiczenia cielesne & 2 & 2 & 2 & 2 & 2 & 2 & 2 & 14 \\
\hline Razem & 19 & 22 & 27 & 28 & 30 & 30 & 30 & 186 \\
\hline
\end{tabular}

Tabela 2. Plan pracy gimnazjum ogólnokształcącego

\begin{tabular}{|l|c|c|c|c|c|}
\hline \multirow{2}{*}{\multicolumn{1}{|c|}{ Przedmioty }} & \multicolumn{4}{c|}{ Klasa } & \multirow{2}{*}{ Ogólem } \\
\cline { 2 - 6 } & I & II & III & IV & 8 \\
\hline Religia & 2 & 2 & 2 & 2 & 16,5 \\
\hline Język polski & $6 / 3^{*}$ & 4 & 4 & 4 & 14,5 \\
\hline Język łaciński & $0 / 5^{*}$ & 4 & 4 & 4 & 17 \\
\hline Język obcy & $6 / 4^{*}$ & 4 & 4 & 4 & 10,5 \\
\hline Historia & 3 & 3 & 3 & $3 / 0^{*}$ & 8,5 \\
\hline Geografia & 3 & 3 & 2 & $0 / 3^{*}$ & 8 \\
\hline Przyroda & 3 & 3 & - & 2 & 8 \\
\hline Fizyka i chemia & - & - & 4 & 4 & 15 \\
\hline Matematyka & 3 & 4 & 4 & 4 & 8 \\
\hline Zajęcia praktyczne & 2 & 2 & 2 & 2 & 8 \\
\hline Ćwiczenia cielesne & 2 & 2 & 2 & 2 & 122 \\
\hline Razem & 30 & 30 & 31 & 31 & 8 \\
\hline
\end{tabular}

*) liczba godzin w pierwszym i drugim półroczu

Źródło: Wytyczne dla autorów programów... 1933, s. 47 
O ile włączenie do programów przedmiotów humanistycznych, takich jak język polski, historia czy wiedza o Polsce współczesnej, oraz zagadnień obywatelskowychowawczych wydawało się proste, o tyle w przypadku nauk ścisłych wymagało pogłębionej refleksji i zastanowienia. Ostatecznie treści z zakresu państwowości i kultury polskiej zostały wprowadzone do nauczania języka polskiego, religii rzymskokatolickiej i historii. Naturalnie, obiektem największej troski sanacyjnych ideologów pozostawało nauczanie języka polskiego jako podstawowego nośnika idei wychowawczych, zwłaszcza patriotycznych, czemu wielokrotnie dawano wyraz na łamach sztandarowych czasopism pedagogicznych i wydawnictw zwartych, dbając o jego właściwy wydźwięk ideologiczny (Kosiński 1930, s. 188-210; WalekCzernecki 1930, s. 348-369; Dancewiczowa 1933, s. 30; Drzewiecki 1934a, s. 21-44; Saloni 1936). Niewątpliwie to język polski, prowadzony we wszystkich klasach na poszczególnych szczeblach edukacyjnych w wymiarze największej liczby godzin, pełnił kluczową rolę w propagowaniu wychowania państwowego. Najefektywniejszą w szkole powszechnej i to w najmłodszych klasach, gdyż to na tym etapie dzieci zdobywały ogólną wiedzę o otaczającym je świecie, ucząc się go obserwować i opisywać. Wówczas to kształtować się miała świadomość przynależności do rodziny, grupy, kraju oraz poczucie więzi z najbliższym środowiskiem, stanowiące punkt wyjścia do budowy postawy obywatelskiej. Podobnie czytanie lektur szkolnych czy utworów literackich (w większości polskich autorów) oraz ich analiza i interpretacja w swym założeniu miały służyć poznaniu kultury polskiej i naśladownictwu postaw patriotycznych czy obywatelskich w ujęciu indywidualnym jak i zbiorowym. Już bowiem „[...] od I klasy zapoznawano dzieci z najważniejszymi postaciami (prezydent, marszałek Piłsudski) czy symbolami państwowymi oraz obrazami historycznymi o wyraźnie patriotycznej wymowie. W klasach starszych dużo uwagi poświęcano wybitnym postaciom w dziejach Polski - wodzom, królom, uczonym, pisarzom" (Sadowska 2001, s. 230). Opowiadając o Polsce współczesnej należało to czynić w narracji pozytywnej, wręcz patetycznej, podkreślając przy tym znaczenie odbudowy niepodległego państwa, będącego dziełem wysiłku całego społeczeństwa. Wskazywanie na jego silną pozycję i ciągłość dziedzictwa miało spotęgować u najmłodszych wiarę w wartość własnego narodu i jego dorobku kulturalnego.

Dużą wagę w konstruowaniu programów szkolnych przywiązywano również do wychowania religijnego. I chociaż trudno określić wyraźną ingerencję ze strony państwa w wychowawczą wymowę tego przedmiotu, to można zauważyć pewne ślady dostosowania go do tendencji programowych. Dla przykładu w szkole powszechnej bardziej eksponowano postacie polskich świętych czy analizowano wydarzenia roku kościelnego w kraju. Utożsamiono wiarę z głównym źródłem siły duchowej i „siły oporu” (Sadowska 2001, s. 227). Ponadto w programie do 
nauki religii w szkołach powszechnych pisano, iż „,...] w ciągu całej pracy szkolnej nauczyciel winien rozwijać religijne pobudki miłości Ojczyzny i pracy dla dobra Państwa na każdym stanowisku. Wskazywano, że od początku nauczania życie religijne dziecka powinno być ukazywane z związku z polskością i najbliższym środowiskiem - miejscowy kościół, obrzędy, polscy święci" (Program nauki religii rzymsko-katolickiej... 1938, s. 33).

Z kolei w programie gimnazjum znalazła się praktyczna wskazówka: „[...] uczący religii kapłan-Polak winien zwrócić baczną uwagę na wychowanie obywatelskopaństwowe poruczonej mu młodzieży, jak najserdeczniejszą opieką otaczając modlitwę uczniów o błogosławieństwo Boskie dla Państwa Polskiego i o jego potęgę, nabożeństwa państwowe, związane z nimi egzorty itp." (Program nauki w gimnazjum państwowym... 1933, s. 14).

W podstawie przewidziano także nauczanie języka łacińskiego w gimnazjach ogólnokształcących oraz w liceum klasycznym i humanistycznym. Walorów wychowawczych nie brakowało wszakże w lekturze tekstów antycznych i wiadomościach dotyczących kultury starożytnej. Podobnie w odniesieniu do nauczania języków obcych nowożytnych zakładano przekazywanie informacji z zakresu kultury, życia państwowego i codziennego innych narodów. Rzecz jasna, chodziło o „[...] uświadamianie odrębności i wartości własnego narodu, zyskiwaniu szerszej perspektywy na świat, uczeniu się tolerancji, pogłębianiu uczucia sprawiedliwości i ogólnoludzkiej solidarności, kształceniu uczuć humanitarnych" (Program nauki w gimnazjach państwowych... 1934, s. 222-223).

O dominującej, wiodącej roli nauczania historii w realizacji wychowania państwowego dzieci i młodzieży świadczy chociażby miejsce, jakie zajęła wśród wszystkich przedmiotów szkolnych w nowych siatkach nauczania. W latach 19181932 znajdowała się ona na 6-7 pozycji zestawień godzinowych (po religii, języku polskim i przedmiotach matematyczno-przyrodniczych). Ustawa Jędrzejewiczowska podniosła jej rangę do 3 miejsca w planach pracy szkół powszechnych (po religii i języku polskim) (Glimos-Nadgórska 2015, s. 263).

Do 1932 r. w niepodległej Polsce cele kształcenia historii na poziomie szkoły powszechnej koncentrowano wokół rozwijania zainteresowania przeszłością, wybitnie w kontekście teraźniejszości i przyszłości. Od wprowadzenia reformy J. Jędrzejewicza założenia te „[...] ograniczono i podporządkowano innym [...], zwłaszcza utylitarnym, dlatego nie były sformułowane osobno, lecz łącznie z celami materialnymi i poznawczymi zgodnie z wytyczoną osią programową" (Kulczykowska 1972, s. 84-91). Można zgodzić się z opinią Anny Radziwiłł, iż historia po myśli nowych programów ujęta została fragmentarycznie, bez wykazania związków genetycznych i pragmatycznych między faktami, w metodach jej nauczania króluje intuicjonizm, „wczucie się” w epokę i psychologizm (Radziwiłł 1966, 
s. 121; Sadowska 2001, s. 284-286). Świadomie decydowano się na akcentowanie momentów pozytywnych, uwydatniających rozkwit państwowości polskiej. Zaś ujemne strony w polskiej historii miały być przedstawiane w takim ujęciu, by wzbudzić w uczniach wiarę w pokonywanie wszelkich trudności i przeszkód. Historia „[...] ma kształtować w młodzieży uczucie miłości Ojczyzny, przywiązanie do Państwa, dumę z przynależności do niego i szacunek do jego tradycji, oraz dać elementarne przygotowanie do pełnienia w przyszłości obowiązków obywatelskich" (Program... trzeciego stopnia. Historia (Projekt) 1933, s. 284; Program... pierwszego stopnia. Historia 1935, s. 266; Program... drugiego stopnia z jezzykiem polskim... 1936, s. 323). Przy wyborze materiału kierowano się przede wszystkim wartościami wychowawczo-utylitarnymi oraz użytecznością treści w życiu obywatelskim. Eksponowano te pożyteczne dla przeciętnego obywatela, który z historii miał czerpać wiedzę konieczną dla zrozumienia teraźniejszości (Magiera 2003, s. 66; szerzej: Konopka, Wójcik-Łagan, Stępnik 1986; Glimos-Nadgórska 2010, s. 21-32). Badacze edukacji zajmujący się tamtym okresem twierdzą, iż kształcenie historyczne na poziomie szkoły powszechnej było zorganizowane nie tyle z myślą o uczniu, ile w zgodzie z potrzebami narodu, państwa i władzy. Przyczyn tak anachronicznego i niepedagogicznego podejścia upatrywano w „[...] świadomej polityce władz preferującej tradycyjny model edukacji, łatwiejszy do zorganizowania i nadzorowania" (Osiński 2010, s. 29; szerzej: Kulczykowska1972, s. 96-97; Glimos-Nadgórska 2015, s. 273).

W podobnej konwencji organizowano propedeutykę tzw. edukacji obywatelskiej realizowanej w ramach lekcji historii. Jej program kształcenia, noszący nazwę „nauki o Polsce współczesnej” wprowadzano w II półroczu VII klasy, zamiast typowej historii, w wymiarze 4-6 godzin w zależności od stopnia organizacyjnego szkoły powszechnej. Zbliżone treści realizowano też na lekcjach historii w kl. IV gimnazjum (Kulczykowska 1972, s. 64; Konopka 1986, s. 112; Sadowska 2001, s. 214, 220-221; Magiera 2003, s. 66-67). „Nauki o Polsce współczesnej” swoim zakresem obejmowały wiadomości z organizacji państwa, jego władz, obronności, obowiązków i praw obywateli - wprowadzając ten przedmiot zakładano między innymi zdobycie przez ucznia podstawowego zasobu wiedzy, który pozwoliłby mu odnaleźć się w strukturze narodowej, politycznej, społeczno-gospodarczej państwa polskiego i - co istotne - wyrobić czynną postawę obywatelską (Arnold 1930, s. 334-347; Chałasiński 1930, s. 844-865; Dutkiewicz 1937 s. 408-414). Ale - co najistotniejsze - podczas kursu przyszły patriota dowiadywał się o swojej służebnej funkcji wobec państwa. Na tym właśnie etapie zamierzano wpoić mu akceptację dla pewnych konieczności ustrojowych, a mianowicie „podziału czynności: władza i podwładni, karność i przymus” czy „potrzeby stworzenia silnej organizacji państwowej uzasadnianej przykładami z dziejów Polski”, co przecież wykluczało 
samodzielny osąd i ograniczało merytoryczną dyskusję (Sadowska 2001, s. 210). Charakter zajęć przywodził na myśl prowadzoną wcześniej „naukę o Polsce” jednakże już o zupełnie innej wymowie ideologicznej. Poza tym nie wykazywano ich w siatkach nauczania przez cały okres międzywojenny. Wprowadzono je jedynie do programu licealnego (Radziwiłł 1966, s. 114; por. Hoszowska 1933b).

Obok historii i języka polskiego to geografia, określana jako „ośrodek wychowania”, zdawała się przedmiotem szczególnie „podatnym” na przyjętą wymowę ideową i wychowawcze zadania zreformowanej szkoły. Od klasy V szkoły powszechnej geografia stawała się przedmiotem samodzielnym. Postawiono przed nią zadanie, aby „[...] nauczyć miłości ziemi rodzinnej, jej tradycji i kultury i wyrabiać czynną postawę obywatelską" (Program... trzeciego stopnia. Historia (Projekt) 1933, s. 299). Akcentowano jej wychowawczo-państwową rolę, którą miała realizować: 1) dając konkretne wiadomości o składnikach geograficznych; 2) wprowadzając uczniów w całokształt stosunków gospodarczych i demograficznych państwa;3) ucząc czytania i rozumienia mapy; 4) wyjaśniając stosunek człowieka do ziemi; 5) pozwalając porównywać własne państwo z innymi; 6) budząc umiłowanie ziemi ojczystej. „Dzięki tak określonej roli i odpowiedniemu doborowi materiału uczeń będzie mógł zdać sobie sprawę z roli i znaczenia Polski na kuli ziemskiej, a z pewnością pierś jego rozpierać będzie radość i duma z tego, że Polska we wszystkich prawie epokach i czasach obecnych pracą rąk i umysłów swych obywateli przysparza dóbr kulturalnych i materialnych całemu światu" (Michałowska 1935, s. 47). Słowa te w zupełności oddają ideę przewodnią przyjętą w nowych programach szkolnych. Ze względów wychowawczych to przede wszystkim geografia Polski stanowiła podstawę programu, również $\mathrm{w}$ gimnazjum, jako najbliższa środowisku ucznia stawała się prosta do obserwowania, a tym samym stanowiła punkt wyjścia dla nauki o świecie - jej prymat uznawano więc za zasadny. Jednak zdaniem niektórych ówczesnych dydaktyków wymiar geografii nie został dostatecznie przemyślany, również pod względem metodycznym. Ideowi nauczyciele zwracali uwagę, iż w okresie wielkich przemian politycznych, których są świadkami, koniecznym jest skoncentrowanie się w nauczaniu na kwestiach geografii politycznej, aby wykształcić u najmłodszych orientację we współczesnym świecie, co zresztą było zgodne z założeniami nowej szkoły. „W gimnazjach nowego typu geografia zacieśniła nieco już zbyt rozluźniony związek z historią, oparta jest jednak nadal, i to ściśle, na podłożu przyrodniczym. Cierpi na tym geografia polityczna, na którą pozostaje bardzo mało czasu" (Hłasko-Pawlicowa 1936 217-219; Mścisz 1936, s. 297-300).

Pomocniczą rolę w wychowaniu państwowym wpisującą się w oś programową „Polska i jej kultura” przypisano również nauczaniu biologii. Nauka o przyrodzie pojawiała się w klasie III szkoły powszechnej razem z geografią i dopiero od klasy $\mathrm{V}$ stawała się odrębnym przedmiotem. W założeniu sam fakt wprowadzenia dziecka 
w świat przyrody otwierał przed nauczycielem możliwość budzenia w wychowanku doznań odnoszących się do postaw obywatelskich, ale w praktyce nie było to takie proste. W przypadku biologii treści nauczania w większości mają bowiem charakter poznawczy, trudniej za to odnaleźć walory wychowawcze, służące wykształceniu „twórczego obywatela”. Przewidywano w tym względzie następujące cele nauczania: 1) uczenie poszanowania życia we wszelkich przejawach; 2) wytworzenie uczuciowego stosunku do przyrody ojczystej; 3) wyrobienie czynnej postawy i zaradności w życiu codziennym; 3) zaangażowanie w prace na rzecz podnoszenia poziomu gospodarczego, a w konsekwencji uświadomienie znaczenia takiej działalności dla gospodarki państwa. Ponadto w klasach V i VI szkoły powszechnej program kształtował etykę obywatelską, wdrażając hasło ochrony wszystkiego co żyje i co życiem swoim nie zagraża człowiekowi (Program... trzeciego stopnia. Historia (Projekt) 1933, s. 312-313). Zalecano wykorzystanie nauki o przyrodzie martwej dla celów wychowania obywatelskiego, eksponując jej znaczenie gospodarcze i środowiskowe oraz związek z kulturą całej Polski, poprzez powiązanie poszczególnych zagadnień z określonymi terenami Polski oraz ukazanie znaczenia dla państwa rzetelnej pracy jednostki i zespołu (Magiera 2003, s. 69). W zakresie metod kształcenia, zwłaszcza na etapie nauki gimnazjalnej, znaczny nacisk położono na obserwacje prowadzone w trakcie wycieczek szkolnych i doświadczenia w formie uprawy i hodowli, zajęć w ogrodzie szkolnym i ćwiczeń laboratoryjnych (Program nauki w gimnazjum państwowym..., 1937, s. 70-72, 277-291).

W związku z koncepcją praktycznego kształcenia, program nauki przyrody chwalono za dostosowanie do życia, ograniczenie wiadomości teoretycznych, podporządkowanie strony formalnej względom dydaktycznym. Zarazem obawiano się, że realia szkolne, tj. przewidziana liczba godzin, znaczna liczebność klas, braki w wyposażeniu pracowni, nie pozwolą zrealizować założeń. Gimnazjum często też krytykowano za plan godzin przewidujący przerwę w nauczaniu przyrody w klasie III, co zaburzało ciągłość i utrudniało pracę w klasie IV (Kosiński 1937, s. 212-213).

Kurs przedmiotów matematycznych (obecnie ścisłych) w szkole powszechnej odbywał się na lekcjach arytmetyki z geometrią, w gimnazjum zaś obejmował matematykę i od III klasy wprowadzał dodatkowo fizykę i chemię. Mając na względzie formalny charakter nauk matematycznych i znaczny stopień abstrakcji, doszukiwanie się w nich znaczenia dla wychowania państwowego wydaje się być zabiegiem „na wyrost”. Jednakowoż autorzy programów i na tej płaszczyźnie znaleźli rozwiązanie (Aleksandrzak 1933; Machowski 1933, s. 22-24; Berger 1933/34, s. 53-58). Wychowawczą koncepcję oparli na oczywistym, praktycznym zastosowaniu podstaw nauk matematycznych w życiu codziennym. W szkole powszechnej program arytmetyki z geometrią dosłownie „[...] nakładał na zadania matematyczne obowiązek służby obywatelskiej; służyć one muszą przysposobieniu 
gospodarczemu wychowanków" (Program... trzeciego stopnia. Historia (Projekt) 1933, s. 348). Uczniowie mieli rozumieć znaczenie pojęć matematycznych i umieć stosować wiedzę z tego zakresu w praktyce. Dodatkowo wytyczne zakładały skłanianie dzieci do „liczenia się z groszem”, wypracowanie nawyku samodzielnego oszczędzania i tworzenia rezerw, które były bardzo ważne dla gospodarki społecznej. „Lekcje należało upraktycznić, uatrakcyjnić, nadać »kolorów życia«, wprowadzić zagadnienia życiowe, wydobyć te wartości, które były pomocne w kształtowaniu uczuć obywatelskich" (Magiera 2003, s. 70). Podobnie podstawa gimnazjalna nauki fizyki i chemii zalecała „(...) poznanie znaczenia tych dziedzin nauki dla bezpieczeństwa, dobrobytu i kultury Polski i wyrobienie szeregu cech i umiejętności potrzebnych w pracy indywidualnej i zespołowej”. Wbrew pozorom nauki matematyczne w nowej szkole nosiły zatem wybitnie pragmatyczny i utylitarny charakter (Program nauki w gimnazjum państwowym... 1937, s. 292-293).

Sposób organizowania zajęć artystyczno-technicznych w zreformowanej szkole (szczególnie powszechnej) został w całości podporządkowany celom wychowywania państwowego i obywatelskiego. Nauka rysunku powinna przede wszystkim rozwijać wrażliwość estetyczną, otwierać na piękno przyrody i ojczystego krajobrazu, pogłębiać znajomość polskiej kultury plastycznej, zachęcać do praktycznego stosowania zasad estetyki życia codziennego. Prócz tego zalecano dobór odpowiedniej tematyki prac plastycznych, najlepiej uwzględniającej potrzeby ówczesnego życia gospodarczego i politycznego, np. przedstawiające ludzi przy pracy, żołnierzy, symbole narodowe, polski krajobraz. Nauczyciele winni też zapoznawać uczniów z polską sztuką i folklorem regionu. Tematy lekcji powiązać miano z praktycznymi potrzebami ucznia i jego otoczenia (Program... trzeciego stopnia. Historia (Projekt) 1933, s. 368).

Zajęcia praktyczne widniejące w programach szkolnych wszystkich szczebli edukacyjnych już same w sobie służyły idei wychowania państwowego. Zastąpiły wcześniejsze „roboty ręczne” i pomyślane zostały w taki sposób, by obok typowych zajęć rękodzielniczych obejmowały pracę w gospodarstwie domowym, zajęcia ogrodnicze i hodowlane oraz pojawiającą się po raz pierwszy tzw. kulturę życia codziennego. Po języku polskim i historii, traktowano je jako zasadnicze dla potrzeb życia gospodarczego. Nadawały w ten sposób systemowej edukacji rys „szkoły pracy”, realizując przy tym wyznaczone cele, tj. wyrabiania u uczniów zmysłów praktycznych, pogłębiania zdolności technicznych, samodzielność i spostrzegawczość. Z kolei rozwijanie kultury osobistej, wpajanie zamiłowania i szacunku do pracy fizycznej, zwłaszcza zespołowej, czy wzbudzanie poczucia odpowiedzialności i karności służyło wykształceniu obywatela inicjatywnego „[...] przysposobionego do realnej pracy dla wzniesienia na wyższy poziom życia gospodarczego państwa” (Program... trzeciego stopnia. Historia (Projekt), 1933, s. 385-386). Zbliżenie uczniów 
do współczesnego życia gospodarczego, wytwórczości rzemieślniczej i rolniczej posiadało charakter wychowania techniczno-utylitarnego. Aby skutecznie wypełniać postawione zadania, zalecano np. dobór prac i materiałów, który zapewni nie tylko poznanie aktualnego poziomu technicznego i gospodarczego, ale też wskaże drogi rozwoju poprzez „[...] częste organizowanie pracy zespołowej, nawiązywanie do miejscowych tradycji rękodzielniczych, odwiedzanie pobliskich zakładów pracy, zwłaszcza tych stosujących nowoczesne technologie" (Program... trzeciego stopnia. Historia (Projekt), 1933, s. 388; szerzej: Hoszowska 1933a; Michałowska 1933, s. 74-78; Sadowska 2001).

Niepodważalne walory wychowawczo-ideologiczne w szkołach powszechnych posiadała nauka śpiewu, a szczególnie pieśni, którą postrzegano jako „towarzyszkę życia”. Niosąca ze sobą ładunek pozytywnych uczuć, stanowiła korzystne podłoże do wychowania państwowego. Wrażliwość muzyczna „[...] ożywia uczuciowość dziecka, wyrabia pogodę ducha, zbliża do kultury ludowej, a śpiew chóralny kształci instynkt społeczny, uczy łączenia wysiłków dla wspólnego celu” (Program... trzeciego stopnia. Historia (Projekt), 1933, s. 316; Program...Śpiew... 1935, s. 20). Zachęcano do uczenia pieśni, szczególnie tych o zabarwieniu emocjonalnym, religijnym, patriotycznym, traktujących o rodzinie i szkole, gdyż „wpływały one na kształtowanie się charakteru i stosunku do ojczyzny obywatela odrodzonej Polski” (Łempicki 1939, s. 185; por. Przerembska 2008, s. 11-22).

W kręgu przedmiotów wpływających na postawy obywatelskie znalazły się też ćwiczenia cielesne, które służyły „(..) zdrowiu, sprawności, dzielności i pięknu wychowanka. Wyrabianiu dzielności duchowej przez kształcenie takich cech jak miłość umysłu, odwaga, siła woli, umiejętność opanowania się, wytrwałość, solidarność" (Program... trzeciego stopnia. Historia (Projekt), 1933, s. 431). Ćwiczenia cielesne, poprawiając tężyznę fizyczną, ucząc musztry, adaptując do dyscypliny, wreszcie - rozbudzając odwagę i siłę woli umacniały w wychowankach gotowość do obrony kraju i dumę z tego, że stają się prawdziwymi obywatelami (Chmura, Doering 1933; Ubysz 1933, s. 300-317; Wittekówna 1935, s. 54-60).

Idea obronności - stanowiąca podbudowę postawy przyszłych żołnierzyobywateli - zawarta w materiałach programowych wychowania fizycznego obecna też była w założeniach dydaktycznych innych przedmiotów. Zasad obrony państwa poszukiwano również w tych z obszaru nauk humanistycznych. Nasilenie realizacji zagadnień z zakresu obronności nastąpiło w 1937 r., po wydaniu ministerialnego zarządzenia w sprawie organizacji przysposobienia młodzieży szkolnej do obrony kraju, w którym przygotowanie to uznano za podstawowy element pracy dydaktycznej i wychowawczej każdej szkoły. W nauce poszczególnych przedmiotów miano szczególnie „[...] kłaść nacisk na te zagadnienia, które mają związek z obronnością państwa i otaczać specjalną opieką ćwiczenia cielesne jako podstawę przysposo- 
bienia wojskowego młodzieży" - zalecało rozporządzenie (Dz.U. MWRiOP 1937, $\mathrm{nr} 11)$. Typowe zajęcia $\mathrm{z}$ „przysposobienia wojskowego" pojawiły się na etapie liceum, w wymiarze 2 godzin tygodniowo przez cały dwuletni okres nauki. Prowadzono je oddzielnie dla chłopców i dziewcząt, w oparciu o odrębne podstawy (Program nauki w liceum ogólnokształcącym... Przysposobienie wojskowe 1937, s. 3-6). Na uwagę zwraca fakt, że programy licealne odróżniało od gimnazjalnych i szkół powszechnych niewielkie wyeksponowanie zagadnień wychowawczych i ideologicznych. Te dotyczące wychowania państwowego pojawiały się niejako na marginesie, w pojedynczych zdaniach, w niektórych próżno ich szukać. Wyjaśnić to można ogólnym charakterem programów licealnych oraz dojrzałym wiekiem uczniów, w dużej mierze już ukształtowanych ideowo. Dodatkowo pojawienie się w szkole średniej odrębnego przedmiotu - „Zagadnienia życia współczesnego” mogło zwolnić autorów poszczególnych programów z umieszczania w nich celów związanych z wychowaniem państwowym (szerzej Sadowska 2001).

\section{PODSUMOWANIE}

Systemat wychowania państwowego, będący odzwierciedleniem ideologii wychowawczej sanacji, stanowił kryterium doboru szczegółowych treści poznawczych i wychowawczych programów szkolnych wszystkich szczebli edukacyjnych. Celów nauczania najczęściej w nich nie wyodrębniano, były one jedynie elementem egzemplifikacji celów wychowawczych. Było to wyraźnie dążenie do zastąpienia dotychczasowej szkoły nauczającej szkołą wychowującą. Nowe programy nauczania miały bowiem oddziaływać przede wszystkim na emocjonalną i wolicjonalną stronę osobowości młodego obywatela, intelektualny rozwój następowałby „wtórnie”, w sposób podporządkowany, urzeczywistniając dominację woli nad rozumem. Reforma Jędrzejewiczowska zdecydowanie podkreślała praktyczny wymiar wiedzy, adaptując na swój użytek nawet metody „nowego wychowania” czy inne funkcjonujące naówczas teorie pedagogiczne i psychologiczne, podnosiła efektywność i atrakcyjność wychowania państwowego. Zabiegi te pozwalały także zamaskować nadmierną ideologizację życia szkoły. Przewaga argumentów politycznych i ich dominacja nad pedagogicznymi przybierał niejednokrotnie formę tendencyjną, wręcz indoktrynującą, oscylującą wokół haseł, rytuałów i symboli narodowych. Wszelako, przy ocenie systemu nauczania, należy mieć na względzie ówczesne realia geopolityczne i fakt, że forsowanie idei wychowania państwowego opartego na poczuciu obywatelskiego obowiązku i wspólnej pracy dla dobra kraju mogło ułatwić narodowi polskiemu przetrwanie II wojny światowej. 


\section{LITERATURA}

\section{ŹRÓDŁA DRUKOWANE}

AKTY PRAWNE

Dz.U. MWRiOP 1937, R. 20, nr 11.

Ustawa o ustroju szkolnictwa. (Projekt komisji, powołanej przez ministra Wyznań Religijnych i Oświecenia Publicznego), 1927. Warszawa.

Sejm Rzeczypospolitej Polskiej. Okres III. Druk nr 508.

\section{INNE MATERIAŁY ŹRÓDŁOWE}

Program nauki religii rzymsko-katolickiej w publicznych szkołach powszechnych pierwszego stopnia z polskim językiem nauczania, 1938. Lwów.

Program nauki w gimnazjach państwowych z polskim językiem nauczania (tymczasowy), 1934. Lwów.

Program nauki w gimnazjum państwowym. Religia rzymsko-katolicka, 1933. Lwów.

Program nauki w liceum ogólnokształcącym. Przysposobienie wojskowe. Wydział humanistyczny, klasyczny, matematyczno-fizyczny i przyrodniczy. (Projekt), 1937. Lwów. Program nauki w publicznych szkołach powszechnych drugiego stopnia z polskim językiem nauczania, 1936. Lwów.

Program nauki w publicznych szkołach powszechnych pierwszego stopnia. Historia (Projekt), 1935, Lwów.

Program nauki w publicznych szkołach powszechnych pierwszego stopnia. Śpiew (Projekt), 1935. Warszawa-Lwów.

Program nauki w publicznych szkołach powszechnych trzeciego stopnia z polskim językiem nauczania (tymczasowy), 1934. Lwów.

Program nauki w publicznych szkołach powszechnych trzeciego stopnia. Historia (Projekt), 1933. Warszawa-Lwów.

Program nauki w publicznych szkołach powszechnych trzeciego stopnia. Geografia, 1935. Lwów.

Wytyczne dla autorów programów szkół ogólnokształcących. Szkoła powszechna. Gimnazjum, 1932. Lwów. 
Wytyczne dla autorów programów szkół ogólnokształcących. Szkoła powszechna

I i II stopnia o 5 i 6 nauczycielach, 1934, Lwów.

\section{ARTYKUŁY I OPRACOWANIA PRZED 1939}

Aleksandrzak S., 1933, Jak realizować wychowanie państwowe terenie szkoły w związku z nauczaniem rachunków?. „Praca Szkolna”, nr 12.

Araszkiewicz F.W., 1978, Ideały wychowawcze Drugiej Rzeczypospolitej. PWN, Warszawa. Araszkiewicz F.W., 1971, Geneza ustaw z roku 1932 o szkolnictwie państwowym i powszechnym. „Przegląd Historyczno-Oświatowy”, z. 4.

Arnold S., 1930, Teoretyczne podstawy Nauki o Polsce Współczesnej. „Zrąb”, t. 3.

Balicki J., 1934, Prace Ministerstwa nad programami szkół ogólnokształcących w związku z realizacją ustawy o ustroju szkolnictwa. „Oświata i Wychowanie”, nr 8-10.

Berger A., 1933/34, Wychowanie obywatelsko-państwowe w nauczaniu matematyki. „Praca Szkolna”, nr 3.

Bystroń J.S, 1934, Szkoła jako zjawisko społeczne. Skł. Gł. Książnica-Atlas, Warszawa. Chałasiński J., 1930, Dwie koncepcje nauki obywatelstwa i dwa typy podręczników. „Oświata i Wychowanie”, z. 9.

Chmura F., Doering M., 1933, Ćwiczenia cielesne w szkole powszechnej. Nakładem S-ki Wydawniczej A. Gmachowski i S-ki Częstochowa.

Czerwiński S., 1934, O nowy ideał wychowawczy. Wydawnictwo Towarzystwa Kultury i Oświaty, Warszawa.

Dancewiczowa I., 1933, Jak realizować nowy program języka polskiego, cz. I. Gebethner i Wolff, Warszawa.

Drzewiecki S., 1934a, Wychowanie obywatelsko-państwowe a nauka języka polskiego. W: Z teorji i praktyki wychowania. Wydaw. Kuratorjum Okręgu Szkolnego, Warszawa.

Drzewiecki S., 1934b, Wychowanie obywatelsko-państwowe w nowych programach. Gebethner i Wolff, Warszawa.

Dutkiewicz J., 1937, Dydaktyka nauki obywatelstwa, [w:] Encyklopedja wychowania, t. 2, pod red. S Łempiskiego i in. Wydaw. „Naszej Księgarni” Zw. Naucz. Polskiego, Warszawa.

Hłasko-Pawlicowa A., 1936, Więcej geografii politycznej. „Gimnazjum”, nr 6 Hoszowska W., 1933a, Zajęcia praktyczne w zakresie kultury życia codziennego w szkole powszechnej. Nasza Księgarnia, Warszawa.

Hoszowska W., 1933b, Jak realizować nowy program historii, cz. 1. Gebethner i Wolff, Warszawa.

Jędrzejewicz J., 1930, Współczesne zagadnienie wychowawcze. „Zrąb” nr 1. 
Kijas J., 1932, Wychowanie obywatelsko-państwowe w nauczaniu języka polskiego. „Polonista”, r. II, z. 4.

Kosiński K., 1930, Wychowanie obywatelskie a nauka historii literatury w szkole średniej. „Zrąb”, t. 2.

Kosiński M., 1937, Biologia w nowym gimnazjum. „Przegląd Pedagogiczny”, nr 14.

Kuchta J., 1934, Psychologja dziecka wiejskiego a praca szkolna: ze szczególnym uwzględnieniem „zajęć cichych”. Gebethner i Wolff, Warszawa.

Łempicki S., 1939, Polska pieśń narodowa jako czynnik wychowawczy. „Kultura i Wychowanie", z. 2.

Machowski S., 1933, Wychowanie gospodarcze w nowych programach. Gebethner i Wolff, Warszawa.

Michałowska J., 1935, Oblicze nowych programów. Gebethner i Wolff, Warszawa.

Michałowska J., 1933, Zagadnienia wychowawcze w nowych programach. Gebethner i Wolff, Warszawa.

Mścisz M., 1936, Geografia w nowym programie gimnazjum ogólnokształcacego. „Gimnazjum”, nr 8/9.

Petrykowski R., 1927, O naprawę programu szkolnego. Metoda pracy nad reforma programu powszechnej. Związek Polskiego Nauczycielstwa Szkół Powszechnych, Warszawa.

Pohoska H., 1934, Wychowanie obywatelsko-państwowe. W: S. Łempicki i in. (red.), Encyklopedia wychowania, t. 1: Wychowanie, cz. 2. Wyd. „Naszej Księgarni”, Związku Nauczycielstwa Polskiego,Warszawa.

Saloni J., 1936, O celach nauczania języka polskiego, „Polonista”, z. 4.

Skwarczyński A., 1934, Myśli o nowej Polsce. Drukarnia Artystyczna, Warszawa.

Śliwiński F., 1928, Ustawodawstwo szkolne i organizacja polskich władz szkolnych oraz szkolnictwa wszystkich stopni w wszystkich stopni w Polsce Odrodzonej. Rada Szkolna Okręgowa Łódzka, Łódź.

Ubysz S., 1933, Ćwiczenia cielesne jako czynnik wychowania moralnego. „Kwartalnik Pedagogiczny", nr 3-4.

Walek-Czernecki T., 1930, Kultura klasyczna a wychowanie państwowe. „Zrąb”, t. 3. Wittekówna M., 1935, Wychowanie fizyczne w służbie ideału. „Zrąb”, t. 22.

\section{ARTYKUŁY I OPRACOWANIA PO 1939}

Bartnicka K., 1972, Wychowanie państwowe. „Rozprawy z dziejów oświaty”, t. 15, Wrocław.

Felchner A., 2014, Współczesne dylematy wokół wychowania państwowego. „Prace Naukowe Akademii im. Jana Długosza w Częstochowie. Pedagogika”, t. 23, s. 15-31. 
Garbowska W., 1976, Szkolnictwo powszechne w Polsce w latach 1932-1939. Wrocław, Zakład Narodowy im. Ossolińskich.

Glimos-Nadgórska A., 2010, Edukacja historyczna w Drugiej i Trzeciej RP - podobieństwa i różnice $w$ kontekście sytuacji politycznej. W: M. Fic, L. Krzyżanowski, M. Skrzypek (red.), Dwa dwudziestolecia Rzeczypospolitej. Oświata - religia - kultura i społeczeństwo. Próba bilansu, t. 1. 4DPlus, Katowice.

Glimos-Nadgórska A., 2015, Miejsce nauczania historii w polskim systemie edukacyjnym XX wieku. „Prace Historyczne”, nr 142(2).

Grochowski L., 1996, Studia z dziejów polskiej szkoły i pedagogiki lat międzywojennych: w kontekście europejskim. Warszawa, Żak.

Iwanicki M., 1986, O ideowo-wychowawczym oddziaływaniu sanacji na młodzież szkolna i akademicka. Siedlce, WSR-P.

Jakubiak M.A., 2003, Ideologia wychowawcza sanacji. „Saeculum Christianum”, nr 1. Juśko E., Patriotyzm w wychowaniu szkolnym dziś i wczoraj. Działania wychowawcze szkół powszechnych powiatu tarnowskiego w zakresie patriotyzmu w latach 1918-1939 www.kul.pl/files/803/biblioteczka_cyfrowa/jusko_Patriotyzm_w_wychowaniu.pdf

Juśko E., 2003, Szkolnictwo powszechne w powiecie tarnowskim w latach 1918-1939. Lublin, TNKUL.

Kamińska J., 2014, Wokół pacy doktorskiej Anny Radziwiłł. „Kwartalnik Pedagogiczny", nr 1-2.

Konopka H., 1986, Spór o oblicze ideowo-wychowawcze szkoły polskiej w latach 1918-1939. W: J. Maternicki (red.), Problemyedukacji historycznej i obywatelskiej młodzieży w latach 1918-1939. Warszawa, Centralny Ośrodek Metodyczny Studiów Nauk Politycznych.

Konopka H., Wójcik-Łagan H., Stępnik A.,1986, Problemy edukacji historycznej i obywatelskiej młodzieży w latach 1918-1939. Warszawa, Centralny Ośrodek Metodyczny Studiów Nauk Politycznych.

Kulczykowska A., 1972, Programy nauczania historii w Polsce 1918-1932. PWN, Warszawa.

Magiera E., 2003, Wychowanie państwowe w szkolnictwie powszechnym Drugiej Rzeczypospolitej. Szczecin, Wydawnictwo Naukowe UŚ.

Malinowski L., 2015, Wychowanie państwowe w Drugiej Rzeczypospolitej. Warszawa, Wydawnictwo Akademii Pedagogiki Specjalnej.

Przerembska V., 2008, Ideały wychowania w edukacji muzycznej w II Rzeczypospolitej. Łódź, Wydawnictwo Uniwersytetu Łódzkiego.

Radziwiłł A., 1966, Ideologia wychowawcza sanacji i jej odbicie w polityce szkolnej w latach 1926-1939. Warszawa, maszynopis pracy doktorskiej sygn. WH 530-269.

Radziwiłł A., 2014, Ideologia wychowawcza sanacji i jej odbicie w polityce szkolnej w latach 1926-1939. „Kwartalnik Pedagogiczny”, 59, nr 1/2. 
Sadowska J., 2001, Ku szkole na miarę Drugiej Rzeczypospolitej. Geneza, założenia i realizacja reformy Jędrzejewiczowskiej. Białystok, Wydawnictwo Uniwersytetu w Białymstoku.

Sadowska J., 2004, Wychowanie państwowe i jego odbicie w programach szkolnych doby sanacji. „Res Historica”, z. 16.

\author{
STATE EDUCATION IN THE SECOND POLISH REPUBLIC \\ IN THE LIGHT OF CURRICULA AFTER THE INTRODUCTION \\ OF THE EDUCATIONAL REFORM OF 1932
}

\begin{abstract}
The idea of ensuring Poland the status of power, promoted by Józef Piłsudski's camp, entailed the need to create a strong state organization and shape consolidated society, homogenous in respect of its world view, solidarily and persistently working for the highest good, that is, the state, if taken into consideration the rhetoric of the sanation camp. This could not be done without the adoption of the appropriate educational doctrine and its conversion into an efficient educational system covering possibly the broadest spectrum of society. As a result, crystallising after 1926, the educational ideology of the sanation became known as the so-called state education, which, by shaping the desired ideal of the citizen - the state adherent - was expected to "remedy" social relations in the country. The school reform of 1932, bringing a new program framework, became its conceptualization. By pointing out shallowness of goals drawn in the old curricula and their excessive vagueness, the authors of the new core curriculum focused on the very practical character of teaching. The slogan that followed it was "Poland and its culture". It was expected that emphasisng the cultural heritage of Poland would have an integrative value in the ethnically diversed society of the Second Polish Republic. This gave rise to an implication that Poland was the legacy of many nations that created its cultural mosaic, contributing in a unique manner to the continuity of the state, despite its formal, over 100-year absence both on maps and in human consciousness. According to new assumptions, the most important for every citizen was to respect the value of the state, to be devoted to its development, to shape a sense of civic responsibility regardless of belonging to the specified national group. The promotion of these patterns had to take place on many levels of social life, not only on the institutional one. Hence, emphasis was placed on linking didactic work with educational influence and school work with non-school activities. This article deals with the assumptions of curricula in a relation to teaching contents referring to the state education.
\end{abstract}

Keywords: state education, ideology, curricula, sanation, integration 